\title{
PENGARUH PENGGUNAAN DANA PEMBANGUNAN FISIK DESA TERHADAP PNGURANGAN TINGKAT KEMISKINAN DI KECAMATAN JANGKA KABUPATEN BIREUEN
}

\author{
Ernita $^{\text {a }}{ }^{1}$, Cut Putri Melita Sari ${ }^{\text {a }} 2$ \\ ${ }^{a}$ Fakultas Ekonomi dan Bisnis Universitas Malikussaleh \\ 1 Corresponding author: Ernita49515@gmail.com \\ 2 cmellita07674@gmail.com
}

\section{A R T I CLE INFORMATIONABSTRACT}

Keywords:

Amount Fund, Building, Level

Poverty
The study aimes to see the effect the amount of funding, of village building on the level of poverty in the Jangka Subdistrict Bireuen District. The study uses panel data from 21 villages during 2017 to 2018 derived from $a$. sub-district office. The research uses multiple regression for analyging the data. The result showed that the total budget do not affect the level of poverty.

\section{PENDAHULUAN}

Kemiskinan di aceh menjadi salah satu fenomena yang belum bisa diatasi meskipun penyaluran dana desa setiap tahun meningkat akan tetapi tingkat kemiskinan justru meningkat. Jumlah penduduk miskin di Aceh pada bulan Maret 2018 mencapai 830 ribu orang $(15,97$ persen), Tingkat kemiskinan bertambah sebanyak 10 ribu orang dibandingkan dengan penduduk miskin pada September 2017 yang jumlahnya 829 ribu orang $(15,29$ persen $)$, Tetapi jika dibandingkan satu tahun sebelum Maret 2017, Jumlah penduduk miskin di Aceh menurun sebanyak 33 ribu orang (16,89 persen). Terjadi penurunan 0,92 persen dibandingkan Maret 2018. (BPS Provinsi Aceh)

Pembangunan fisik perdesaan melalui dana desa oleh Kementrian Desa Republik Indonesia merupakan salah satu program pembangunan yang dimuat dalam Undang-undang Desa di samping pemberdayaan dan pemerintahan perdesaan. Pembangunan fisik ini diarahkan guna meningkatkan kualitas sumber daya manusia dan peningkatan aset desa agar mampu memandirikan desa.

Kecamatan Jangka terletak dalam geografis Bireuen. Kecamatan ini setiap tahunnya melakukan pembangunan fisik maupun non fisik dengan dana desa yang dikucurkan setiap tahunnya. Di Kecamatan Jangka, Kabupaten Bireuen, diberikan program Dana Desa. Jangka merupakan daerah pesisir yang berbasis perikanan yang masuk kategori sebagai desa belum berkembang meskipun sudah dicanangkan sebagai daerah minapolitan oleh Dinas Perikanan dan Kelautan Kabupaten Bireuen. Adapun sebagian besar penduduknya bekerja di sektor petani, perikanan atau sebagai nelayan, sebagai buruh dan pekerja konstruksi dan juga pedagang serta pegawai swasta dan pegawai negeri sipil (BPS Bireuen, 2018).

Tabel 1

Jumlah Anggaran, Jumlah Bangunan dan Tingkat Kemiskinan di Beberapa Desa Di Kecamatan Jangka Tahun 2017-2018

\begin{tabular}{|c|c|c|c|c|}
\hline No & Tahun & $\begin{array}{l}\text { Jumlah } \\
\text { Anggaran } \\
\text { (Rp) }\end{array}$ & $\begin{array}{c}\text { Jumlah } \\
\text { Bangunan } \\
\text { (unit) }\end{array}$ & $\begin{array}{c}\text { Tingkat } \\
\text { Kemiskinan } \\
(\mathrm{KK})\end{array}$ \\
\hline \multicolumn{5}{|c|}{ Paya Bieng } \\
\hline 1 & 2017 & 410.495 .000 & 6 & 63 \\
\hline 2 & 2018 & 503.700 .000 & 7 & 60 \\
\hline \multicolumn{5}{|c|}{ Mns. Krueng } \\
\hline 1 & 2017 & 494.392 .000 & 5 & 28 \\
\hline 2 & 2018 & 410.800 .000 & 5 & 21 \\
\hline \multicolumn{5}{|c|}{ Jangka Alu U } \\
\hline 1 & 2017 & 580.276 .000 & 4 & 75 \\
\hline
\end{tabular}


\begin{tabular}{l|l}
2018 & 600.615 .000
\end{tabular} 4

sumber : kantor camat jangka

Berdasarkan Tabel 1 diatas , jumlah anggaran pembangunan fisik Desa Paya Bieng, Jangka Alu U, mengalami peningkatan dari tahun 2017-2018, namun di Mns. Krueng mengalami penurunan. Pengalokasian jumlah anggaran fisik di beberapa desa di atas pada tahun 2017 menjadi fenomena seperti di Desa Mns. Krueng, pada tahun 2017 anggaran yang dikucurkan lebih besar dengan jumlah bangunan fsik yang dibangun sama dengan tahun 2018, namun tingkat kemiskinan tahun 2018 lebih menurun hingga $21 \mathrm{KK}$.

Secara teori, peningkatan jumlah anggaran pembangunan fisik akan mampu mendorong pertumbuhan ekonomi dan pendapatan masyarakat, dengan demikian jumlah angka kemiskinan akan menurun.

Demikian juga dengan jumlah bangunan fisik desa sejak tahun 2017-2018 dari dana desa yang dikucurkan oleh pemerintah. Secara nominal, meningkatnya jumlah bangunan fisik desa tidak mampu mengurangi tingkat kemiskinan yang justru bertambah sejak 2017 seperti di Desa Paya Bieng, ketika jumlah bangunan bertambah 1 unit menjadi 7 unit di tahun 2018, angka kemiskinan yang turun hanya $3 \mathrm{KK}$ dari $63 \mathrm{KK}$ menjadi 60 KK. Penambahan kuantitas bangunan fisik di Desa Mns. Krueng dan Jangka Alue U mengalami peningkatan signifikan baik dari segi volume maupun anggaran, namun angka kemiskinan di Desa Jangka Alue tidak menurun signifikan, hal ini tidak memberikan efek apapun adanya pembangunan fisik desa dengan angka kemiskinan.

Hal ini berbeda dengan teori, dimana semakin tingginya jumlah pembangunan fisik akan mengurangi ketimpangan pembangunan dan pemerataan pendapatan dalam rangka penurunan jumlah penduduk miskin, namun yang terjadi adalah sebaliknya.

Permasalahan di atas terjadi karena desa belum mampu mengalokasikan dana yang dibiayai oleh Pemerintah untuk mengurangi kemiskinan, meskipun ada pembangunan, namun pembangunan tidak menjadi income bagi masyarakat, seperti pembangunan saluran, jalan desa dan Meunasah.
Pemerintah Desa masih berkutat pada pola pembangunan yang terlihat secara kasat mata, tanpa melakukan analisis dan kajian secara ekonomi masyarakat.

Permasalahan lainnya adalah pembangunan fisik yang belum tepat sasaran dan tanpa memberikan dampak langsung bagi perekonomian, kebutuhan masyarakat akan lapangan kerja tidak terealisasi dari tahun ke tahun, bahkan tanpa pernah dimasukkan dalam anggaran desa. Puluhan pemuda pengangguran yang memiliki kemauan dan kemampuan dasar seperti bengkel.

Penelitian ini bertujuan untuk mengetahui pengaruh jumlah anggaran pembangunan fisik desa terhadap tingkat kemiskinan dan mengetahui pengaruh jumlah bangunan fisik desa terhadap tingkat kemiskinan.

selanjutnya Bagian kedua dari penelitian ini merupakan kajian teoritis. Metode penulisan di paparkan pada bagian ketiga. Selanjutnya bagian ke empat merupakan hasil dan pembahasan. Akhirnya kesimpulan dan saran pada bagian kelima.

\section{TINJAUAN TEORITIS}

\section{Kemiskinan}

Kemiskinan merupakan kondisi dimana seseorang atau kelompok tidak memiliki sumber daya yang mencukupi kebutuhan hidup, kemiskinan diukur berdasarkan keterbatasan jumlah aset yang dimiliki seseorang, tingkat pendidikan dan kesehatan untuk melakukan aktivitas sehari-hari.

(Aris Triyono, 2018) dalam penelitiannya menunjukkan bahwa pengaruh signifikan Alokasi Dana Desa terhadap kesejahteraan masyrakat.

Hasil penelitian (H. Muhammad Rusydi, 2012) menunjukkan bahwa Anggaran dana desa (ADD) berpengaruh positif dan signifikan terhadap kesejahteraan masyarakat di Kabupaten Takalar. Korelasi (keeratan hubungan) antara anggaran dana desa (ADD) dengan kesejahteraan masyarakat (pendapatan perkapita) adalah bahwa ADD memiliki hubungan yang sangat kuat terhadap peningkatan kesejahteraan masyarakat.

(Mirah, 2017) menyatakan bahwa dana desa untuk pembangunan desa berpengaruh 
signifikan dengan arah positif terhadap penduduk miskin. Arah positifnya menunjukkan bertambahnya dana desa maka bertambahnya jumlah penduduk miskin.

\section{Jumlah Anggaran Fisik Desa}

Dana adalah uang yang disediakan untuk suatu keperluan (KBBI, 2008:314) yang berarti wilayah, tempat atau bagian yang mandiri dan otonom. Aceh memiliki keistimewaan dalam penyebutan Gampong, Sesuai dengan Qanun No 5 Tahun 2003 penyebutan nama desa khusus untuk Aceh disebut Gampong. Gampong memiliki pengertian yang sama dengan desa. Penetapan definisi, pengalokasian dan mekanisme transfer untuk Dana Desa.

Berdasarkan teori jumlah anggaran fisik desa adalah banyaknya uang yang direncanakan atau dianggarkan untuk setiap proyek fisik atau infrastruktur setiap tahun anggaran.

Hasil penelitian Nugraheni, Ananda \& Syafitri (2018) menyatakan hal yang berbeda bahwa alokasi Dana Desa berdampak pada beberpa faktor yang berkaitan dengan tingkat kemiskinan desa yaitu akses kesehatan. Pertambahan jumlah penduduk secara negatif mempengaruhi tingkat kemiskinan. Pada keadaan di lapangan bawah penggunaan dana desa masih di digunakan untuk membangun infrastruktur desa. Sedangkan alokasi anggaran dibidang pemberdayaan masyarakat terbukti berpengaruh terhadap tingkat kemiskinan desa.

(Mahfudz, 2009) dalam menyakan bahwa efektivitas alokasi dana desa (ADD) berpengaruh negatif terhadap tingkat kemiskinan. Arah negatifnya menunjukkan berkurangnya dana desa maka berkurangnya penduduk miskin.

Namun, hasil penelitian (Mirah, 2017) menyatakan Dana Desa tidak efektif dan tidak berhasil dalam mengurangi kemiskinan di tiap Kabupaten/Kota di Provinsi Jawa Timur. Sementara penggunaan bagi pemberdayaan ekonomi masyarakat msih terbilang kecil. Selain itu, kualitas sarana dan prasarana yang dibangun masih kurang baik karena minimnya kemampuan teknis pengolaan, baik dari sisi perencanaan dan pengelolaannya.

\section{Jumlah Bangunan Fisik Desa}

Infrastruktur atau bangunan fisik menurut Grigg (Resti Herdyaningsih, Ansofino, 2015) adalah "semua kegiatan pembangunan fisik desa termasuk dalam anggaran dana desa".

Hasil penelitian Azwardi

menyatakan bahwa alokasi dana desa berpauh negatif dan signifikan terhadap kemiskinan. Arah negatifnya menunjukkan jumlah dana alokasi dana desa meningkat maka bertambahnya kemiskinan.

Hasil penelitian Whisnu adhi Saputra (2011) menyatakan bahwa jumlah penduduk desa berpengaruh positif dan signifikan terhadap kemiskinan .

Berdasarkan teori di atas dapat disimpulkan bahwa jumlah bangunan fisik desa adalah banyaknya bangunan yang direncanakan atau yang telah dibangun dari dana desa dan sumber pendapatan desa lainnya setiap tahun anggaran.

Merujuk pada beberapa penelitian sebelumnya, pembangunan fisik desa ikut menentukan pergerakan sektor ekonomi. Namun, Triyono (2018); Lalira, dkk (2018); Dewi dan Irama (2018) menyatakan bahwa anggaran dana desa tidak berpengaruh terhadap kemiskinan.

\section{Kerangka Konseptual}

Kerangka konseptual menjelaskan secara teoritis pertautan antara variabel-variabel yang akan diteliti. Berikut merupakan skema kerangka konseptual yang akan digunakan peneliti atau penulis dalam melakukan penelitian.

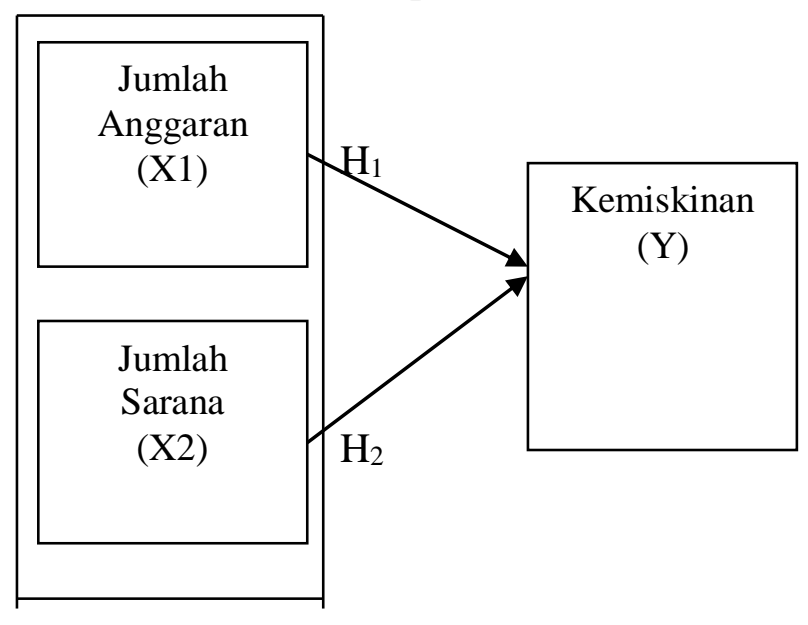

\footnotetext{
Gambar 1 Kerangka Konseptual
} 
Berdasarkan gambar 1 di atas dapat diketahui bahwa penelitian ini menggunakan variabel independen (X) sebagai variabel independen yakni jumlah anggaran pembangunan fisik desa dan jumlah bangunan fisik desa, sedangkan kemiskinan sebagai variabel dependen. Variabel tersebut diuji secara parsial menggunakan uji-t dan simultan dengan menggunakan uji-F.

\section{Hipotesis Penelitian}

Dari penjabaran rumusan masalah dan tujuan penelitian, maka penulis menetapkan hipotesis dalam penelitian ini adalah:

$\mathrm{H}_{1}$ : Jumlah anggaran pembangunan fisik desa berpengaruh terhadap tingkat kemiskinan di Kecamatan Jangka Kabupaten Bireuen

$\mathrm{H}_{2}$ : Jumlah bangunan fisik desa berpengaruh terhadap tingkat kemiskinan di Kecamatan Jangka Kabupaten Bireuen

\section{METODE PENELITIAN}

\section{Data dan Sumber Data}

Sumber data dalam penelitian ini adalah data panel jumlah anggaran pembangunan fisik desa, jumlah bangunan dan tingkat kemiskinan rentang tahun 2017-2018. Data tersebut diperoleh dari Kantor Camat dan dari Kantor Keuchik Keuchik di Kecamatan Jangka Kabupaten Bireuen. Jumlah sumber data yang diambil dalam penelitian ini adalah 21 Desa.

\section{Definisi Operasional Variabel Penelitian}

Berdasarkan rumusan hipotesis penelitian, variabel penelitian terdiri dari dua variabel $\mathrm{X}$ sebagai variabel Independen dan Variabel $\mathrm{Y}$ sebagai variabel dependen. Adapun variabelnya meliputi:

\section{Tingkat Kemiskinan (Y)}

Banyaknya penduduk miskin di Desa di Kecamatan Jangka, diukur dalam satuan KK.

2. Jumlah Anggaran Pembangunan Fisik Desa $\left(\mathrm{X}_{1}\right)$

Besarnya nilai uang yang dikeluarkan untuk membangun sarana dan prasarana desa di Kecamatan Jangka, diukur dalam satuan Rp.

3. Jumlah Bangunan Fisik Desa $\left(\mathrm{X}_{2}\right)$.
Banyaknya pembangunan infrastruktur desa yang telah dibangun oleh Pemerintah Desa di Kecamatan Jangka meliputi jalan, saluran, sarana ibadah, sarana pendidikan dan kesehatan, diukur dalam satuan unit.

\section{Metode Analisis Data}

Untuk menganalisis data dalam penelitian ini adalah dengan menggunakan aplikasi Eviews 9 yaitu:

\section{Analisis Regresi Linier Berganda}

Data yang diperoleh dari data sekunder dokumentasi, kemudian di tabulasi dan diolah dengan menggunakan rumus persentase yang berguna untuk melihat kecenderungankecenderungan indikator dari masing-masing indikator. Data panel yang diolah menggunakan aplikasi pengolah data statistik Eviews series 8.

$$
\mathrm{Y}=\alpha+\beta_{1} \mathrm{X}_{1}+\beta_{2} \mathrm{X}_{2}+\mathrm{e}
$$

$$
\begin{array}{ll}
\mathrm{Y} & =\text { Tingkat Kemiskinan } \\
\mathrm{X}_{1} & =\text { Jumlah Anggaran Pembangunan } \\
& \text { Fisik Desa } \\
\mathrm{X}_{2} & =\text { Jumlah Bangunan Fisik Desa } \\
\alpha & =\text { Konstanta } \\
\beta_{1}, \beta_{2} & =\text { Koefesien yang dicari } \\
\mathrm{e} & =\text { standar error }
\end{array}
$$

Dikarenakan variabel-variabel yang digunakan tidak memiliki satuan yang sama, maka diubah dalam bentuk semi logaritma (Semi-Log). Adapun rumus analisis data adalah sebagai berikut:

$$
\log Y=\alpha+\log \beta_{1} X_{1}+\log \beta_{1} X_{2}+\text { ei }
$$

model regresi data panel ada 3 teknik yang dapat digunakan yaitu:

\section{Common Effect Model}

Model Common Effect merupakan model sederhana yaitu untuk menggabungkan seluruh data time series dengan cross section.

\section{Fixed Effect Model}

Model Fixed effect untuk melihat perbedaan antar data cross section dengan time series. 


\section{Random Effect Model}

Model Random Effect untuk melihat hubungan antar waktu dengan individu.

\section{Uji Normalitas}

Setiap variabel model regresi harus merupakan distribusi normal. Dalam penelitian ini untuk menguji normalitas variabel menggunakan Jarque-Bera test .Jarque-Bera test adalah uji statitistik untuk mengetahui data terdistribusi normal, dan untuk mengukur Jarque-Bera test dengan mencari perbedaan skewness dan kurtusis (Winarno, 2007). Uji Jarque-Bera didistribusi dengan degree freedom sebesar 2. Probabilitas menunjukkan kemungkinan nilai Jarque-Bera melebihi nilai terobservasi dibawah hipotesis nol. Nilai probabilitas yang kecil cenderung mengarahkan pada penolakan hipótesis nol data berdistribusi normal. Untuk mendeteksi normal atau tidak normalnya model regresi, variabel peganggu atau residual. Dengan cara membandingkan nilai $\mathrm{J}-\mathrm{B}$ hitung dengan nilai $\mathrm{C}^{2}$ (Chi-Square) tabel.

\section{Uji Asumsi Klasik}

Uji asumsi klasik secara individu (parsial) menganalisis variabel yang telah ditetapkan diatas untuk melihat pengaruh nyata terhadap pelaksanaan program pelatihan dengan meminimalisir tingkat kesalahan.

\section{Uji Multikolinearlitas}

Multikolinieritas adalah hubungan yang sangat kuat antara variabel-variabel eksplanatoris dalam model regresi. Multikolinieritas mengakibatkan estimasi yang dihasilkan menjadi kurang tepat. Berdasarkan Gujarati (2003; 359) multikolinieritas ini dapat dideteksi dengan: Pertama, nilai determinasi yang tinggi dengan diikuti nilai $F$ statistik yang sangat tinggi, serta tidak ada atau hanya sedikit nilai t-test yang signifikan. Kedua, koefisien matriks korelasi antara variabel yang tinggi (>0.8).

Bila hal di atas ditemukan maka perlu dilakukan auxiliary regression, yaitu variabel regresor yang mengalami dengan variabel regressor lainnya diregresikan untuk menghitung $R^{2}$. Rule of thumb menyarankan bahwa mungkin menimbulkan masalah multikolinieritas jika koefesien determinasi yang diperoleh dari auxiliary regression lebih besar dari koefesien determinasi keseluruhan (Manurung, et al, 2005: Kuncoro, 2004).

Pengujian multikolinieritas juga dapat dilakukan dengan VIF, dimana dalam model regresi tidak terjadi multikolinearitas jika dengan nilai VIF lebih kecil dari 10.

\section{Uji Autokorelasi}

Ada cara yang dapat digunakan untuk mendeteksi ada atau tidaknya autokorelasi. Salah satunya dengan Serial Correlation LM Test yang dengan menggunakan nilai Durbin Waston (Ghozali, 2007).

\section{Koefisien Korelasi ( R )}

Menurut Sugiyono (2009) koefisien korelasi bernilai yang bernilai 0,70 sampai mendekati 1,00 (plus atau minus) menunjukkan derajat hubungan yang tinggi, sedangkan apabila koefisien korelasinya di atas 0,20 sampai 0,40 (plus atau minus) maka menunjukkan derajat hubungan yang rendah.

\section{Koefesien Determinasi $\left(\mathbf{R}^{\mathbf{2}}\right)$}

Analisis ini dipergunakan untuk mengetahui proporsi variabel independen dalam memberikan kontribusinya terhadap variabel dependen dan hasil perhitungan dari analisis ini berupa prosentase. Untuk mengetahui nilai koofisien determinasi dapat diketahui dari nilai adjusted $R$ square pada tabel model summary ${ }^{b}$ dalam output Eviews.

\section{Pengujian Hipotesis}

Uji t

Untuk mengetahui pengaruh variabel bebas secara parsial atau individu terhadap variabel tidak bebas dengan asumsi variabel yang lain konstan. Pengujian ini dilakukan dengan melihat derajat signifikan masing-masing variabel bebas menggunakan Eviews. Jika $\mathrm{t}$ hitung $>\mathrm{t}$ tabel maka hipotesis menyatakan menerima $\mathrm{H}_{\mathrm{a}}$ secara parsial dengan tingkat signifikan $<\alpha=0,05$. Dasar pengambilan keputusan: 
b. Jika probabilitas (signifikan) $>0,05(\alpha)$ maka $\mathrm{H}_{\mathrm{a}}$ ditolak secara parsial.

\section{Uji F}

Untuk menentukan nilai Ftabel, tingkat signifikan yang digunakan sebesar 5\% dengan derajat kebebasan (degree of freedom) $\mathrm{df}=(\mathrm{n}-\mathrm{k})$ dan (k-1) dimana $\mathrm{n}$ adalah jumlah observasi, kriteria uji yang digunakan adalah:

1. Jika Fhitung < Ftabel, maka $\mathrm{H}_{\mathrm{a}}$ diterima artinya secara statistik dapat dibuktikan bahwa variabel independent tidak berpengaruh terhadap variabel dependent.

2. Jika Fhitung > Ftabel, maka $\mathrm{H}_{\mathrm{a}}$ diterima artinya secara statistik dapat dibuktikan bahwa variabel independent berpengaruh terhadap variabel dependent.

\section{HASIL PENELITIAN DAN PEMBAHASAN \\ Hasil Penelitian \\ Hasil Uji Normalitas}

Hasil Uji Normalitas menggunakan jarquebera test .jarque-bera test adalah uji statistik untuk mengetahui data terdistribusi normal. Apabila nilai J-B hitung > nilai C2 tabel, maka nilai residual terdistribusi dengan tidak normal dan apabila nilai J-B hitung < nilai C2 tabel, maka nilai residual terdistribusi dengan normal.
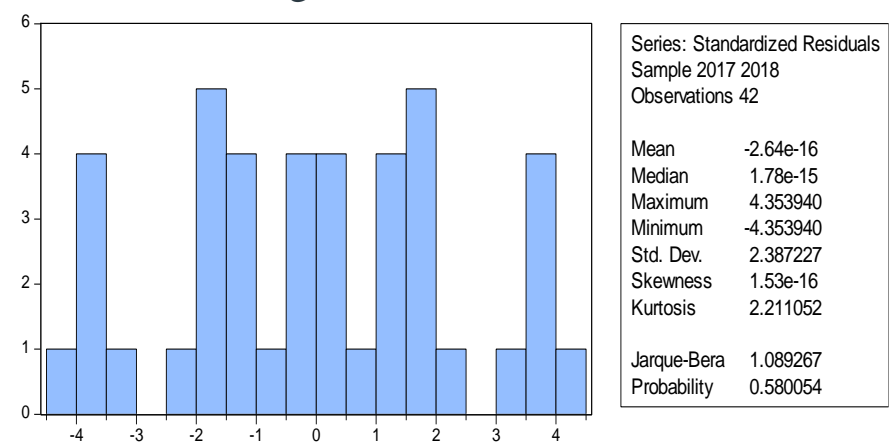

Sumber : Hasil Olah Data, 2019

\section{Gambar 2 Uji Normalitas}

Untuk mengetahui normal atau tidak normalnya model regresi, variabel peganggu atau residual. Dengan cara membandingkan nilai J-B hitung dengan nilai $\mathrm{C}^{2}$ (Chi-Square) tabel. Nilai $\mathrm{C}^{2}$ tabel dengan $\mathrm{df}=42-3=39$. Jika dibandingkan dengan nilai Jarque-Bera pada gambar di atas sebesar 54.572, maka dapat disimpulkan bahwa model regresi, variabel penganggu atau residual terdistribusi normal karena nilai Jarque-Bera < nilai $C^{2}$ tabel atau $1.089267<54.572$.

\section{Hasil Uji Multikolinieritas}

Multikolonieritas adalah adanya hubungan linier yang signifikan antara beberapa atau semua variable independent dalam model regresi.

\section{Tabel 2}

\section{Hasil Uji Multikolinearitas}

\begin{tabular}{|c|c|c|c|}
\hline & $\begin{array}{c}\text { JUMLAH } \\
\text { ANGGARAN }\end{array}$ & $\begin{array}{l}\text { JUMLAH } \\
\text { BANGUNAN }\end{array}$ & $\begin{array}{l}\text { TINGKAT_ }_{-} \\
\text {KEMISKINAN }\end{array}$ \\
\hline JUMLAH_A & & & \\
\hline $\begin{array}{l}\text { NGGARAN } \\
\text { JUMLAH B }\end{array}$ & 1 & 0.279 & 0.159 \\
\hline $\begin{array}{l}\text { ANGUNĀN } \\
\text { TINGKAT } \\
\text { KFMISKIN }\end{array}$ & 0.279 & 1 & 0.175 \\
\hline AN & 0.159 & 0.1750 & 1 \\
\hline
\end{tabular}

Sumber : Hasil Olah Data, 2019

Pada tabel 2 diatas menunjukkan bahwa nilai korelasi matrix dari tiga variabel tersebut kurang dari 0,80, maka dapat dinyatakan bahwa tidak terdapat masalah multikolinearitas dalam model prediksi.

\section{Uji Autokorelasi}

Autokorelasi adalah suatu keadaan dimana terjadinya korelasi antara residual pada satu pengamatan dengan pengamatan lain pada model regresi.

Tabel 3

\section{Uji Autokorelasi}

Mean dependent var 34.54762

S.D. dependent var 17.76157

Akaike info criterion 5.649283

Schwarz criterion 6.600864

Hannan-Quinn criter. 5.998075

Durbin-Watson stat

\section{Sumber: Hasil Olah Data, 2019}

Uji Autokorelasi dalam penelitian ini dilakukan dengan metode Durbin-Waston (DW). Dari model terbaik dalam regresi yang terbentuk yaitu model fixed effect, dapat dilihat bahwa nilai DW dari persamaan regresi yang terbentuk adalah sebesar 2.789902. Sedangkan nilai tabel DurbinWatson dengan $\mathrm{n}=42$ dan $\mathrm{k}=3$, maka diperoleh nilai $\mathrm{dL}=1,3573$ dan $\mathrm{dU}=1,6617$ sehingga nilai 4$\mathrm{dU}=4-1,6617=2,3383$, maka nilai DW dari 
model regresi yang terbentuk pada penelitian ini berada pada area bebas autokorelasi. Dengan demikian $\mathrm{dw}$ (2.789902) terletak antara dU $(1,6617)$ dan $(4-\mathrm{dU})$ atau 2,3383 maka hipotesis nol diterima, yang berarti tidak ada autokorelasi atau $1,3573<2.789902>2,3383$.

\section{Pemilihan Model Data Panel}

Berdasarkan Tabel pada Lampiran Common Effect metode Pooled Ordinary Least Square (Pooled OLS), ada satu variabel dengan test individual (t-test probability) tidak signifikan dengan $\alpha=5 \%$ dan nilai adjusted $\mathrm{R}^{2}$ sebesar 0.000507, pada Durbin-Watson test-nya yaitu sebesar 1.114000 (jauh dari range angka 2) yang menandakan adanya masalah outokorelasi. Sehingga metode pooled regression atau Metode Common effect perlu membandingkan hasil data yang diolah dengan menggunakan metode Fixed Effect. Untuk menentukan model yang dipilih antara Pooled dengan Fixed perlu dilakukan Uji Chow.

\section{Uji Chow}

Uji chow digunakan untuk memilih antara common effect model dan fixed effect model.

\section{Tabel 4}

Uji Chow

Redundant Fixed Effects Tests

Equation: Untitled

Test cross-section fixed effects

\begin{tabular}{lrrl}
\hline \hline Effects Test & Statistic & d.f. & Prob. \\
\hline \hline & 49.09947 & & \\
Cross-section F & 8 & $(20,19)$ & 0.0000 \\
Cross-section Chi-square & 166.5008 & & \\
Suln & 25 & 20 & 0.0000
\end{tabular}

Sumber: Hasil Olah Data, 2019

Berdasarkan hasil di atas ditunjukkan pada tabel 4.4, bahwa kita dapat mengetahui nilai $\mathrm{p}$ value > maupun chi-square kedua model signifikan ( $\mathrm{p}$-value $>5 \%$ ). Hal ini sesuai dengan kriteria pengujian yang telah dijabarkan terlihat bahwa hasil dari uji Chow yakni pada probability chi-square sebesar 0,0000 lebih kecil dari 0,05 sehingga dapat disimpulkan pada penelitian ini memilih fixed effect model sebagai model regresi yang cocok.

\section{Uji Hausman}

Hasil dari regresi yang menggunakan model fixed effect yang menggunakan model random effect, menunjukkan hasil yang signifikan, variabel independen berpengaruh signifikan terhadap dependen. Namun kita belum dapat menentukan model mana yang akan kita gunakan. Oleh karena itu diperlukan uji Hausman untuk mengetahuinya. Pada tabel 4.5 disajikan hasil dari uji Hausman yang telah dilakukan dengan menggunakan Eviews 8.

\section{Tabel 5}

\section{Uji Hausman}

Correlated Random Effects - Hausman Test Equation: Untitled

Test cross-section random effects

\begin{tabular}{lccc}
\hline \hline Test Summary & $\begin{array}{r}\text { Chi-Sq. } \\
\text { Statistic }\end{array}$ & $\begin{array}{r}\text { Chi-Sq. } \\
\text { d.f. }\end{array}$ & Prob. \\
\hline \hline Cross-section random & 0.878233 & 2 & 0.6446
\end{tabular}

Sumber: Hasil Olah Data, 2019

Untuk menentukan apakah model Randomeffects atau Fixed-effects yang digunakan, kita harus membandingkan nilai Uji Hausman dengan nilai Chi-Squre. Nilai Chi Square dengan degree of freedom sebanyak independen variabel yaitu dua dan menggunakan nilai signifikansi $5 \%$.

Berdasarkan variabel individu atas uji t-stat tersebut model Fixed yang mendekati nilai yang memiliki nilai signifikansi mendekati 0,05 . Nilai probability dari F-stat senilai 0.000000 memberikan artian bahwa model Fixed tersebut significant. Nilai Adjudt $\mathrm{R}^{2}$ sebesar 0.961019 memberikan nilai tinggi yang cukup memuaskan, namun nilai Durbin-Watson stat sebesar 2.789902 jauh dari nilai range angka 2. Dengan demikian model yang dipilih adalah model fixed effect.

\section{Regresi Panel Data}

Data penelitian ini menggunakan model regresi liniear berganda dengan metode OLS (Ordinary Least Square). Hasil regresi yang diperoleh nantinya akan dilakukan pengujian terhadap signifikansi yang meliputi Uji-t dan UjiF. Untuk pengolahan data digunakan program econometric views (Eviews) sebagai alat untuk pengukuran dan pengujiannya. Hasil etimasi dari 
model adalah sebagai berikut yang disajikan dalam tabel 4.6.

\section{Tabel 6}

Hasil Regresi Panel Data

\begin{tabular}{lcccc}
\hline \hline \multicolumn{1}{c}{ Variable } & Coefficient & Std. Error & t-Statistic & Prob. \\
\hline \hline C & 15.93792 & 58.10053 & 0.274316 & 0.7868 \\
LOG(JUMLAH_ANG & & & & \\
GARAN) & 1.113861 & 4.559534 & 0.244293 & 0.8096 \\
LOG(JUMLAH_BAN & & & & \\
GUNAN) & 2.623151 & 3.406999 & 0.769930 & 0.4508 \\
\hline \hline \multicolumn{5}{c}{ Effects Specification } \\
\hline Cross-section fixed (dummy variables) & & \\
\hline \hline R-squared & 0.981936 & Mean dependent var & 34.54762 \\
Adjusted R-squared & 0.961019 & S.D. dependent var & 17.76157 \\
S.E. of regression & 3.506783 & Akaike info criterion & 5.649283 \\
Sum squared resid & 233.6530 & Schwarz criterion & 6.600864 \\
Log likelihood & -95.63494 & Hannan-Quinn criter. & 5.998075 \\
F-statistic & 46.94495 & Durbin-Watson stat & 2.789902 \\
Prob(F-statistic) & 0.000000 & & \\
\hline \hline
\end{tabular}

Sumber: Hasil Olah Data, 2019

Berdasarkan hasil analisis model regresi yang ditampilkan dalam Tabel 4.6 diatas, maka dapat disusun kedalam regresi linear berganda sebagai berikut:

$$
\begin{aligned}
& \log (\text { Tingkat Kemiskinan })=15.93792+1.113861 \\
& \text { Log }(\text { Jumlah Anggaran })+2.623151 \text { Log }(\text { Jumlah } \\
& \text { Bangunan })
\end{aligned}
$$

Dari persamaan regresi tersebut dapat dilihat bahwa besarnya nilai konstanta sebesar 15.93792 artinya jika jumlah anggaran dan jumlah bangunan konstan, maka tingkat kemiskinan mengalami peningkatan sebesar $15,93 \%$ per Tahun.

Nilai koefisien jumlah anggaran sebesar 1.113861 menunjukkan hubungan positif yang memberi arti bahwa setiap peningkatan jumlah anggaran sebesar $1 \%$ akan meningkatkan tingkat kemiskinan sebesar $1,11 \%$ per tahun dengan asumsi variabel independen lainnya konstan.

Hal ini disebabkan anggaran desa yang dikucurkan oleh pemerintah pusat untuk pembangunan desa tidak dapat dipergunakan untuk hal-hal yang produktif dan membuka lapangan kerja, hanya sebatas proyek fisik semata.

Nilai koefisien jumlah bangunan sebesar 2.623151 menunjukkan hubungan positif yang memberi arti bahwa setiap peningkatan jumlah bangunan sebesar $1 \%$ akan meningkatkan tingkat kemiskinan sebesar 2,62\% per tahun dengan asumsi variabel independen lainnya konstan. Jumlah bangunan fisik masih berupa jalan desa, gorong-gorong, rehab meunasah dan balai pengajian, tidak menjadi ekonomi yang produktif.

Berdasarkan hasil penelitian dapat dilihat bahwa di Gampong Meunasah Krueng memiliki pengaruh signifikan antara jumlah anggaran dan jumlah bangunan terhadap tingkat kemiskinan, hal ini dapat dilihat dari data yang menunjukkan perubahan signifikan penduduk miskin. Hal tersebut disebabkan adanya pembukaan lahan tambak baru oleh pemerintah gampong yang mempekerjakan tenaga kerja dari Meunasah Krueng. Desa lain yang mengalami pengaruh signifikan adalah Paya Bieng, Pulo Seuna, Linggong, Rusep Ara, Bada Barat, Alue Kuta, Meulinteng dan Barat Lanyan. Adanya pengaruh jumlah anggaran dan jumlah bangunan terhadap tingkat kemiskinan di Desa Linggong disebabkan Desa Linggong yang terletak di jalan utama Peusangan-Jangka merupakan daerah strategi perdagangan, di Desa ini telah dibangun toko untuk masyarakat berdagang yang bersumber dari dana desa.

Terjadinya penurunan kemiskinan yang signifikan pada desa Paya Bieng, Pulo Seuna, Rusep Ara, Bada Barat, Alue Kuta, Meulinteng dan Barat Lanyan disebabkan oleh kondisi yang sama yakni adanya beberapa benda fisik yang dibeli seperti mesin holer padi, pembangunan fisik tambak udang serta pasar desa.

\section{Koefisien Determinasi $\left(\mathbf{R}^{\mathbf{2}}\right)$}

Berdasarkan nilai Adjust R-Square diperoleh nilai 0.961019 atau $96,10 \%$ tingkat kemiskinan dipengaruhi oleh dua variabel di atas, sedangkan pengaruh faktor lain sebesar 3,9\%.

\section{Koefesien Korelasi ( R )}

Berdasarkan tabel 6 nilai $R$-Square diperoleh sebesar 0.981936 yang berarti bahwa derajat hubungan variabel dalam penelitian yang tinggi. 


\section{Pembahasan}

\section{Pengaruh Jumlah Anggaran Terhadap Tingkat} Kemiskinan

Dari hasil perhitungan uji secara parsial antara jumlah anggaran terhadap tingkat kemiskinan diperoleh nilai $t$ hitung sebesar 0.244293, serta $t_{\text {tabel }}$ sebesar 2,024 atau $(0.244293<2,024)$ atau signifikansi $(0.8096>0,05)$. Karena nilai signifikansi lebih besar daripada 0,05 dan nilai $t_{\text {hitung }}$ lebih kecil dari pada $t_{\text {tabel }}$ maka dapat disimpulkan bahwa jumlah anggaran tidak berpengaruh terhadap tingkat kemiskinan sehingga hipotesis yang diajukan ditolak kebenarannya.

Hasil penelitian ini menunjukkan bahwa meskipun jumlah anggaran setiap tahun untuk pembangunan infrastruktur ditingkatkan, akan tetapi tidak mampu menurunkan angka kemiskinan, hal ini disebabkan pembangunan fisik yang dibangun oleh pemerintah desa di Kecamatan Jangka lebih kepada fasilitas publik yaitu jalan desa, gedung PKK, dan saluran.

Secara ekonomi, pembangunan fisik seperti jalan di Kecamatan Jangka tidak berdampak langsung pada pendapatan masyarakat karena desa-desa di Kecamatan Jangka bukanlah merupakan daerah yang terisolir, lalu lintas ekonomi bergerak sebagian besar melalui jalan utama desa atau Kecamatan yang telah dibangun sebelumnya. Hasil penelitian ini relevan dengan penelitian yang dilakukan oleh (Aris Triyono, 2018) Lalira, dkk (2018); Dewi dan Irama (2018) yang menyatakan bahwa anggaran dana desa tidak berpengaruh terhadap kemiskinan.

\section{Pengaruh Jumlah Bangunan Terhadap Tingkat Kemiskinan}

Dari hasil perhitungan uji secara parsial antara jumlah bangunan terhadap tingkat kemiskinan diperoleh nilai $t$ hitung sebesar 0.769930, serta $t_{\text {tabel }}$ sebesar 2,024 atau $(0.769930<2,024)$ atau signifikansi $(0.4508>0,05)$. Karena nilai signifikansi lebih besar daripada 0,05 dan nilai $t_{\text {hitung }}$ lebih kecil dari pada $t_{\text {tabel }}$ maka dapat disimpulkan bahwa jumlah bangunan tidak berpengaruh terhadap tingkat kemiskinan sehingga hipotesis yang diajukan ditolak kebenarannya.

Meningkatnya jumlah bangunan fisik tidak mampu mengurangi angka kemiskinan pada 21
Desa di Kecamatan Jangka, hal ini disebabkan bangunan fisik yang dibangun bukan proyek produktif dan berkelanjutan seperti pabrik garam dan lain-lain. Seandainya di Kecamatan Jangka dibangun proyek fisik seperti tempat pengolahan air bersih, pasar desa, dan pabrik garam, mungkin masyarakat akan memperoleh pendapatan, dengan demikian tingkat kemiskinan semakin berkurang. Hasil penelitian ini relevan dengan penelitian yang dilakukan oleh (Aris Triyono, 2018) Lalira, dkk (2018); Dewi dan Irama (2018) yang menyatakan bahwa anggaran dana desa tidak berpengaruh terhadap kemiskinan.

\section{Pengaruh Jumlah Anggaran dan Jumlah Bangunan Terhadap Tingkat Kemiskinan}

Uji F dilakukan untuk melihat pengaruh variabel-variabel independen secara keseluruhan terhadap variabel dependen. Pengujian dilakukan dengan membandingkan nilai $F_{\text {hitung }}$ dengan $F_{\text {tabel }}$. (Sulaiman, 2004). Berdasarkan nilai probabilitas. Jika nilai signifikansi lebih kecil dari 0,05 atau 5\% maka hipotesis yang diajukan diterima atau dikatakan signifikan. Jika nilai signifikansi lebih besar dari 0,05 atau 5\% maka hipotesis yang diajukan ditolak atau dikatakan tidak signifikan.

Berdasarkan tabel 6 di atas dapat dilihat bahwa hasil uji $\mathrm{F}$ menunjukkan nilai $\mathrm{F}$ hitung sebesar 46.94495 dengan signifikansi sebesar 0.0000. Nilai signifikansi tersebut lebih kecil daripada 0.05 sehingga dapat disimpulkan bahwa variabel independen yaitu jumlah anggaran dan jumlah bangunan secara simultan berpengaruh terhadap tingkat kemiskinan di 21 Desa di Kecamatan Jangka.

Hasil penelitian ini relevan dengan penelitian yang dilakukan oleh Triyono (2018); Lalira, dkk (2018); Dewi dan Irama (2018) yang menyatakan bahwa anggaran dana desa tidak berpengaruh terhadap kemiskinan.

\section{KESIMPULAN DAN SARAN Kesimpulan}

Berdasarkan hasil penelitian yang telah dilakukan maka dapat ditarik beberapa kesimpulan sebagai berikut :

1. Jumlah anggaran tidak berpengaruh terhadap tingkat kemiskinan sehingga 
hipotesis yang diajukan ditolak kebenarannya

2. Jumlah bangunan tidak berpengaruh terhadap tingkat kemiskinan sehingga hipotesis yang diajukan ditolak kebenarannya

\section{Saran}

Berdasarkan kesimpulan diatas maka dapat ditarik beberapa saran sebagai berikut :

1. Kepada pemerintah desa atau gampong agar mengalokasikan anggaran pembangunan gampong untuk proyek fisik yang lebih efektif seperti pembukaan pabrik seperti pabrik garam atau industri seperti industri terasi, kerupuk dan industri pengolahan ikan yang dapat membuka lapangan kerja serta menghasilkan pendapatan bagi masyarakat dan juga menghasilkan pendapatan bagi desa.

2. Pemerintah Desa perlu menyusun data yang riil seperti data kemiskinan dan kesejahteraan sosial masyarakat, sebelum memutuskan untuk menentukan program yang akan dibiayai dengan dana desa. Dengan demikian setiap anggaran yang digunakan akan mampu mengurangi tingkat kemiskinan di Desa tersebut.

\section{DAFTAR PUSTAKA}

Aris Triyono. (2018). Pengaruh Lokasi Dana Desa Dan Program Pembangunan Desa Terhadap Kesejahteraan Masyarakat di desa Bukit Lipai Kecamatan Batang Cenaku, 7(01), 57-70.

BPS Bireuen (2018). Kecamatan Jangka dalam Angka 2018. BPS: Bireuen

Chetwynd, Eric, Frances Chetwynd, dan Bertram Spector. (2003). Corruption and Poverty: A Review of Recent Literature. Washington. Dc USA: Management System International.

Ghozali, Imam. (2007). Aplikasi Analisis Multivariate dengan Program IBM SPSS. 20. Semarang: Badan Penerbit Universitas Diponegoro
Gujarati, Damodar. (2003). Ekonometri Dasar. Terjemahan: Sumarno Zain,. Jakarta: Erlangga.

Hasnul, A. G. (2016). The effects of government expenditure on economic growth: the case of malaysia. Global University of Islamic Finance, (71254), 2-15.

H. Muhammad Rusydi. (2012). Pengaruh Alokasi Dana Desa (Add) Terhadap Kesejahteraan Masyarakat Desa Di Kabupaten Takalar. Jurnal Ekonomi Balance, 8(2), 152-176.

Jarnasy, Owin, (2004). Keadilan, Pemberdayaan dan Penanggulangan Kemiskinan. Jakarta. Blantika.

Mahfudz. (2009). Analisis Dampak Alokasi Dana Desa (Add) Terhadap Pemberdayaan Masyarakat Dan Kelembagaan Desa. Organisasi Management, Volume 5(1), 10-22.

Mirah, F. V. T. V. V. J. P. A. D. P. (2017). Dampak Program Dana Desa Terhadap Peningkatan Pembangunan Dan Ekonomi Di Kecamatan Pineleng Kabupaten Minahasa. AgriSosioEkonomi Unsrat, 13, 335-342.

Priyatno, (2010). Teknik Mudah dan Cepat Melakukan Analisis Data. Penelitian dengan SPSS dan Tanya Jawab Ujian Pendadaran. Gaya. Media, Yogyakarta.

Resti Herdyaningsih, Ansofino, Y. E. P. (2015). Pengaruh Pengeluaran Pemerintah Sektor Pendidikan, Pengeluaran Pemerintah Sektor Kesehatan, Pendapatan Asli Daerah (PAD), Inflasi Dan Pengangguran Terhadap Kesejahteraan Masyarakat Di Kota Padang Tahun 2010-2015, 1-14.

Suryawati, (2004). Memahami Kemiskinan Secara Multidimensional $=$ Understanding Multidimension of Poverty. Jurnal Manajemen Pelayanan Kesehatan 2005, $\underline{\text { VIII(3) }}$

Suryana, (2000), Ekonomi Pembangunan: Problematika dan Pendekatan, Jakarta: Salemba Empat

Sugiyono, (2005), Metode Penelitian Kuantitatif Kualitatif dan R\&D. Bandung : Alfabeta 
(2009), Metode Penelitian Kuantitatif,

Kualitatif dan $R \& D, \quad$ (Edisi Revisi)

Bandung : Alfabeta

Wiguna, I.B.W. Satya dan Suresmiathi. (2014). Pengaruh Devisa, Kurs Dollar AS, PDB, dan Inflasi Terhadap Impor Mesin Kompressor dari China. E-Jurnal Ekonomi Pembangunan Universitas Udayana., 3(5): h:173-181.

Winarno, Wing Wahyu. (2007). Analisis Ekonometrika dan Statistik dengan. Eviews. Yogyakarta.UPP STIM YKPN. 